\title{
A new species of silverside from the Late Miocene of NW Iran
}

Giorgio Carnevale, Enayat Haghfarshi, Syrous Abbasi, Habib Alimohammadian, and Bettina Reichenbacher

Acta Palaeontologica Polonica 56 (4), 2011: 749-756 doi: http://dx.doi.org/10.4202/app.2011.0003

The genus Atherina (Atheriniformes, Teleostei) includes five extant brackish and marine species that inhabit the eastern Atlantic, Mediterranean Sea, Black Sea, and Caspian Sea. Several fossil species are known from the Mediterranean and Paratethyan basins. Here we describe a new fossil species, Atherina atropatiensis sp. nov., from Upper Miocene deposits of the intramontane Tabriz Basin in NW Iran, based on well-preserved, articulated skeletons from the Lignite Beds at Baghmisheh-Marzdaran, near Tabriz. The new fossil species closely resembles the Recent A. boyeri, the only extant species of Atherina in the Caspian Sea, from which it can be distinguished by the different relative development of the ascending and alveolar processes of the premaxilla, and the mutual relationship between pleural ribs and dorsolateral process of the basipterygium. The systematic and zoogeographic affinities of $\mathrm{A}$. atropatiensis indicate that the Lignite Beds of the Tabriz Basin were deposited in a euryhaline environment and that a connection between the intramontane Tabriz Basin and the Eastern Paratethys (Southern Caspian Sea) once existed.

Key words: Teleostei, Atheriniformes, Atherina, osteology, palaeogeography, Miocene, Tabriz Basin, Iran.

Giorgio Carnevale [giorgio.carnevale@unito.it], Dipartimento di Scienze della Terra, Università degli Studi di Torino, Via Valperga Caluso, 35 I-10125 Torino, Italy; Enayat Haghfarshi [en_farshy@yahoo.com], Syrous Abbasi [syrus_abbasi@yahoo.com ], Habib Alimohammadian [halimohammadian@gmail.com], Geological Survey of Iran, Meraj Ave., Azadi Sq., Tehran, Iran; Bettina Reichenbacher [b.reichenbacher@1rz.uni-muenchen.de], Department of Earth- and Environmental Sciences, Section Palaeontology \& Geobiology, Richard-Wagner-Str. 10, 80333 Munich, Germany.

This is an open-access article distributed under the terms of the Creative Commons Attribution License (for details please see creativecommons.org), which permits unrestricted use, distribution, and reproduction in any medium, provided the original author and source are credited. 
For Full text (729.5 kB) 